\title{
5 According to His Exalted Kâanûn: Contending Visions of the Muftiship in the Ottoman Province of Damascus (Sixteenth-Eighteenth Centuries)
}

\subsection{I}

Late in his career, after he had already served as the Hanafi mufti of Damascus, ${ }^{1}$ the late eighteenth-century jurist and chronicler Muhammad Khalīl b. 'Alī al-Murādī sat down to write 'Arf al-bashām fìman waliya fatwá Dimashq al-Shām, a biographical dictionary of the Hanafi muftis of Damascus from the Ottoman conquest of the city up to his own time. ${ }^{2}$ In the introduction to this dictionary, al-Murādī explains why he decided to focus on those who held the muftiship of Damascus. In addition, he elaborates on the reasons for the chronological scope of the dictionary-the years of the Ottoman rule in Damascus. It is appropriate to cite this fascinating passage in full:

I wanted to compile a book that would include all the biographies of those who were appointed as muftis in it [in Damascus] from the time of the great sultan, the famous khaqān, the protector of the land and the frontiers, the grace of the eras and the times, the merciful and helper, he who makes flow the fountains of benevolence in this world and [the fountains] of justice, the queller of the people of evil and corruption, the bearer of the standards of the shari $a h$ and righteousness, the uprooter of oppressors, the defeater of tyrants, he who

1 For al-Murādī's autobiography: Muḥammad Khalīl ibn 'Alī ibn Muḥammad ibn Muhammad al-Murādī, Arf al-bashām fīman waliya fatwá Dimashq al-Shām (Damascus: Majma‘ al-Lugha al'Arabiyya, 1979), 144-152.

2 For a general survey on the genre of biographical dictionaries see: Wadād al-Qāḍī, "Biographical Dictionaries as the Scholars' Alternative History of the Muslim Community," in Organizing Knowledge: Encyclopædic Activities in the Pre-Eighteenth Century Islamic World, ed. Gerhard Endress (Leiden and Boston: Brill, 2006), 23-75; Michael Winter, "Historiography in Arabic during the Ottoman period," in The Cambridge History of Arabic Literature, Vol. 6: Arabic Literature in the Post-Classical Period, eds. Roger Allen and D.S. Richards (Cambridge: Cambridge University Press, 2006), 179-184.

Although the biographical dictionary was a fairly common genre throughout the Mamluk and Ottoman period across the Arab lands, a biographical dictionary that was exclusively dedicated to muftis was quite rare. In the core lands of the empire, roughly a contemporary of al-Murādī, Müstaḳ̂mzâde Süleymân Sa‘deddîn Efendî (d. 1787-1788) wrote a biographical dictionary entitled Devḥatü'l-Meşâyih -i Kibâr that is exclusively devoted to muftis: Müstakîmzâde Süleyman Sa'deddîn, Devhatü'l-Meșâyih: Einleitung und Edition (Stuttgart: Steiner Verlag, 2005), 2 vols. See also Richard Repp, The Müfti of Istanbul: A Study in the development of the Ottoman learned hierarchy (London: Ithaca Press, 1986), 11.

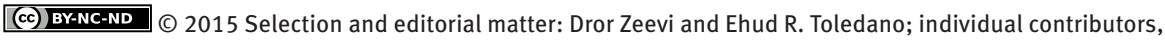
their contributions. 
holds the throne, he who is auspiciously assisted by God, the Iskandar of the time and its Anushrevān, the Mahdi of the time and its Sulimān, the Ottoman Sultan Salīm Khān, let him be enrobed with [God's] merciful contentment. This [the book starts] when he entered Damascus, renewed its affairs, implemented his edicts in it, and organized it according to his exalted qānūn, which is in accordance to the honorable shar. [He also] arranged its [the city's] offices of knowledge and siyāsa according to his ability and his noble opinion. This was in 922 [AH/1516AD]. Among these [new regulations] was the assignment the position of the mufti (takhșiș al-iftä) of each school to a single person, and so he did with the judgeship. The kings and sultans before him, while they appointed a single person to the judgeship, left the affairs of issuing fatāwā to the 'ulamā': the 'ulamā' of each school issued their opinion when they were asked [on a certain issue], they answered [lit. wrote] questions, and there was constant dispute and strife among them [the jurists]. This was the state of affairs in Damascus until Sultan Salīm Khān entered the city, conquered it, and arranged its affairs. [Then] he eradicated from the people of stubbornness their rebelliousness, mastered the rulings [of the fitā', and conducted [it] according to the pure shar' its [the position of the mufti's?] regulations. His successors, the honorable Ottoman kings, employed this manner of assigning the muftiship of each school to a single person from the 'ulamä' of the school, and prevented all the other [jurists] from answering questions, and so was the case with the judges, up until our time in the rest of their land. ${ }^{3}$

In this introductory paragraph, al-Murādī points to the existence of two radically different perceptions of the relationship between the mufti and the ruler on the eve of the Ottoman conquest of the Arab lands. The pre-Ottoman, the "Mamluk," model, explains al-Murādī, advances the independence of the mufti from state authorities, since the muftiship is an internal concern of the community of jurists and religious scholars. In the Ottoman understanding of the muftiship, by contrast, it is the sultan who appoints the juris consult. Although al-Murādi does not explicitly detail the implications of the different models, he seems to imply that the change was deeper than a change in the appointment procedure. The nature of the institution of the mufti and its role within the legal (and political) system were at stake.

In al-Murādī's eyes, the Ottoman conquest of the Arab lands led to an abrupt and intense encounter of these perceptions (or models). The aftermath of this encounter was decisive-the "Ottoman perception" of the muftiship trumped. Fittingly, the office of the mufti in general and specifically that of the Hanafī mufti of Damascus, which up to 1516 had followed the pre-Ottoman model, underwent considerable change, as it was modeled in congruence with the Ottoman perception of the office.

al-Murādī's description of the transformation of this office during the three centuries since the Ottoman conquest may be read on several different levels. First, in the passage al-Murādi unfolds his understanding of the history of the office he held for several years. Secondly, and perhaps more importantly for the purpose at hand, this passage may be read as al-Murādī's attempt to reconcile the tension between his knowledge of what he considered the pre-Ottoman understanding of the institu-

3 al-Murādī, 'Arf al-bashām, 2-3. 
tion of the mufti and the current Ottoman practice. Thirdly, it is quite possible, as we shall see below, that al-Murādī was defending this change in response to allegations against the transformation the office of the mufti had undergone in the past three centuries, allegations that stemmed precisely from the tension between different understandings of the institution of the mufti.

Several decades before al-Murādī wrote the aforementioned introduction, another prominent Hanafi jurist, the Damascene 'Abd al-Ghanī al-Nābulusī (d. 1731), had composed a treatise in which he responded to some statements made by al-Hașkafī, most likely, 'Alā' al-Dīn al-Ḥașkafī, the seventeenth-century stateappointed Hanafi mufti of Damascus, concerning the nature of the legal ruling and the muftiship. As will be discussed, al-Nābulusī's understanding of the muftiship and of the relation between the sovereign and the muftis is different from al-Murādī's and al-Hașkafī’s. By engaging al-Nābulusī on the one hand and al-Murādī and al-Hașkafĩ on the other in a dialogue, this chapter aims at reconstructing the debate among leading Damascene jurists over the course of the seventeenth and the eighteenth century concerning the nature of the office of the mufti and its relations with the Ottoman state authorities. Moreover, it seeks to explore the implication of this debate for understanding the nature of the institution of the mufti in the Ottoman Empire in general and in the province of Damascus in particular. Finally, I will try to show how the debate concerning the Hanafī muftiship of Damascus might open new directions for thinking about the relation between kânûn and şerî at in the Ottoman Empire.

\subsection{II}

None of the three "interlocutors"-al-Ḥașkafī, al-Nābulusī, and al-Murādī-in this debate was a contemporary of the other two. The lives of the three cover a span of almost two centuries. The debate in which they all took part, however, links some aspects of their biographies. My intention here is not to offer a comprehensive biography of these jurists. Rather, it is an elucidation of the debate. So instead of introducing the participants in this debate chronologically, the following survey attempts to explain the differing viewpoints between al-Ḥașkafī and al-Murādī on the one hand, and al-Nābulusī on the other.

Muḥammad b. 'Alī b. 'Alī b. 'Abd al-Raḥman b. Muhammad b. Jamāl al-Dīn b. Ḥasan b. Zayn al-‘̄̉bidīn, also known as 'Alā’ al-Dīn al-Ḥaṣkafī (1616-1677), was born in Damascus. He started his training course in Damascus, but in the following decades he travelled to learning centers in Palestine and the Hijaz. Among his teachers was the prominent Palestinian jurist Khayr al-Dīn al-Ramlī, with whom he studied Hanafi jurisprudence. Later in his career, al-Ḥaṣkafī travelled to Istanbul, where he procured the appointment to his first teaching position. Then he left this office and 
was appointed to the muftiship of Damascus, an office he held for five years. ${ }^{4}$ Like al-Ḥașkafī, Muḥammad Khalīl b. 'Alī al-Murādī was a native of Damascus. In addition, he was a member of the al-Murādī family, many of whom, including al-Murādī’s father, held the state-appointed Hanafi mutfiship of the city over the course of the eighteenth century. During his stay in Istanbul in 1758, Muhammad al-Murādī was also appointed to the Hanafi muftiship in Damascus. ${ }^{5}$

Although more will be said on the institution of the provincial muftis below, it is appropriate to say a few words at this point on the appointment of the Hanafi muftis in Damascus. Soon after the Ottoman conquest of Greater Syria, a graduate of the Ottoman education system who was also a member of the burgeoning religious-judicial establishment was sent from Istanbul to serve as the mufti of the city. Nevertheless, as al-Murādī's biographical dictionary suggests, in the decades following the conquest, the Hanafī mufti that was sent from the imperial capital up until the late sixteenth century was not the sole Hanafī mufti in Damascus.

Two significant changes took place during the late sixteenth and the early seventeenth centuries. First, as Abdul Karim Rafeq has pointed out, ${ }^{6}$ from the end of the sixteenth century onwards the office was manned by prominent Damascene Hanafīs. The reason for this shift from Rūmī (i.e., graduates of the Ottoman medrese system) Hanafīs to Damascene ones is not fully clear. Nonetheless, the distinction between the Rūmī muftis of Damascus and the state-appointed Hanafī muftis of Damascene origin should not be overstated. As Martha Mundy and Richard Saumarez Smith have convincingly shown, the Damascene state-appointed muftis gradually adopted, followed, and defended the opinions of their colleagues in the core lands of the empire. ${ }^{7}$

The second change concerns the exclusivity of the appointed mufti. It seems that by the second half of the seventeenth century an imperial edict had been issued ordering only state-appointed Hanafi mufti the authority to issue legal rulings. Fittingly, the Ottoman state authorities, such as the chief judge in Damascus, prevented muftis who did not hold the appointment from issuing their legal rulings. ${ }^{8}$ Despite this edict, the

4 Muhammad Amīn b. Faḍl Allah al-Muhibbī, Khulāṣat al-athar fī-a’yān al-Qarn al-ḥādī 'ashar (Beirut: Dār al-Kutub al-'Ilmiyya, 2006), Vol. 4, 63-65.

5 al-Murādī, 'Arf al-bashām, 144-152; on the al-Murādī family of Damascus see, for example: John Voll, “Old 'Ulama Families and Ottoman Influence in Eighteenth Century Damascus”, American Journal of Arabic Studies, III: 48-59.

6 Abdul Karim Rafeq, The Province of Damasucs, 1723-1783 (Beirut: Khayats, 1966), 49. There were exceptions: The Bosnian-born Faḍl Allāh b. 'Isā al-Būsnāwī (d. 1629), served as the mufti of Damascus in the early decades of the seventeenth century. Several decades later, Muhammad b. Qubād, known as al-Sukūtī (d. 1643), who entered the city with the chief qadi, Mehmet b. Yüsuf (known as Nihali) in 1605, served as mufti. As his epithet suggests, his origin was from the town of Vidin. See: al-Muhibbī, Khulāṣat al-athar, 4, 124-125; al-Murādī, 'Arf al-bashām, 72-73.

7 Martha Mundy and Richard Saumarez Smith, Governing Property, Making the Modern State: Law, Administration, and Production in Ottoman Syria (London and New York: I.B. Tauris, 2007), 11-39.

8 al-Muhibbī, Khulāṣat al-athar, vol. 2, 310. 
picture that emerges from seventeenth-century chronicles and biographical dictionaries is more complex. As the case of 'Abd al-Ghanī al-Nābulusī indicates, the activity of certain muftis who did not hold a state appointment continued unmolested. It is thus possible that at certain times the Ottoman state authorities were more insistent on the exclusivity of the appointed muftis than in others. Alternatively, the eminence of these particular non-appointed muftis may account for their undisturbed activity.

Be the case as it may, 'Abd al-Ghanī al-Nābulusī represents the second type of muftis that operated in Bilād al-Shā'm. Although al-Nābulusī had held an official appointment as a mufti for a short while before he was removed from this office, ${ }^{9}$ his prestige and authority as jurist rested mostly on his learning and scholarly achievements. Therefore, al-Nābulusī continued to be an important jurisprudential figure in Greater Syria whose opinion was sought. In this respect, his case resembles these of other Greater Syrian jurists, such as the Gazan Muhammad b. 'Abd Allāh al-Timurtāshī ${ }^{10}$ and the renowned Palestinian jurist Khayr al-Dīn al-Ramlī. ${ }^{11}$ These prominent scholars, it should be stressed, never held a state-appointed office and their authority rested first and foremost on their scholarly prestige and their credentials.

This is not to say, however, that the three muftis were not loyal subjects of the empire. Al-Nābulusī, for example, compiled a poem in 1694 praising the Ottoman dynasty and the Ottoman sultan at the time, Ahmed II (1691-1695). And like al-Ramlī, he also granted permits to transmit his teachings (ijāza) to government officials, including the Grand Vezir 'Alî Paşa (d. 1716). Al-Nābulusī had also some sympathizers among the Ottoman governors in Damascus. In 1716, the Ottoman governor in the city, for instance, asked him to compile an exegetical treatise. ${ }^{12}$

On the other hand, at times al-Nābulusī did not hesitate to criticize Ottoman officials. He subtly criticized, for example, the Grand Vezir Mușțafâ Köprülü for being too favorable to ward Serbian Christians. In another instance, al-Nābulusī disapproved of the imperial land tenure policy. ${ }^{13}$ And, as we shall see, al-Nābulusī took issues

9 Barbara Rosenow von Schlegell, Sufism in the Ottoman Arab World: Shaykh 'Abd al-Ghani alNābulusi (d. 1143/1731), (Berkeley: unpublished Ph.D. dissertation, University of California, Berkeley), 110.

10 Anonymous, Tarjmat Muḥammad al-Timūrtāshī, MS Es’ad Efendî 2212-1; al-Muhibbī, Khulāṣat alathar, vol. 3, 459-460.

11 On Khayr al-Dīn al-Ramlī see: Judith E. Tucker, “The Exemplary Life of Khayr al-Dīn al-Ramlī," in Auto/Biography and the Construction of Identity and Community in the Middle East, ed. Mary Ann Fay (New York: Palgrave, 2001), 9-17; Ibid., In the House of the Law: Gender and Islamic Law in Ottoman Syria and Palestine (Berkeley: University of California Press, 1998), 31-32; Haim Gerber, "Rigidity Versus Openness in Late Classical Islamic Law: The Case of the Seventeenth-Century Palestinian Mufti Khayr al-Dīn al-Ramlī,” Islamic Law and Society, 5(2) (1998): 165-195; Haim Gerber, Islamic Law and Culture, 1600-1840 (Leiden: Brill, 1999).

12 Von Schlegell, Sufism, 96-101.

13 Mundy and Smith, Governing Property, 25-26. 
with the Ottoman understanding of the institution of the mufti. ${ }^{14}$ But before we turn to al-Nābulusî's critique it is worth dwelling on the Ottoman understanding of the muftiship and on how it differed from the pre-Ottoman function of muftis during the late Mamluk sultanate.

\subsection{III}

When the early eighteenth-century Ottoman historian Na'îmâ commemorated the appointment date (the year 1024AH/1615) of Mehmet Efendî to the chief muftiship instead of his predecessor, Șun'ullah Efendî, he decided to do so by composing a chronogram: "Cling to the opinion of Mehmet [Efendî] and according to this [opinion, you] should rule." 15 This chronogram, it should be stressed, is not merely a rhetoric device or a decorative word-game. It captures Na'îmâ's (and others') understanding of the nature of the office of the imperial chief mufti, the şeyhülislâm, and of the importance of the chief mufti's legal opinion.

From around the mid-fifteenth century, roughly around the conquest of Istanbul, the Ottoman ruling and religious elites gradually developed a hierarchy of judiciary positions and learning institutions (medreses). An integral aspect of this process was the emergence of the chief mufti, the şeyhülislâm, "to become, by the mid-sixteenth [century], the supreme office in the Ottoman judicial hierarchy." ${ }^{16}$ As part of the consolidation of this learned establishment, the office of the provincial mufti emerged as well.

In his Telhîṣül-Beyân fi Kevânîn-i Âl-i Osmân, the seventeenth-century ${ }^{17}$ historian and encyclopedist Hezârfen Hüseyin Efendî dedicates a section to the taxonomy of muftis in the Ottoman Empire: "the mufti might be the şeyhülislâm, or he might not. Those who are not the şeyhülislâm are the provincial muftis (kenâr müfiîeri)." ${ }^{18}$ Hezârfen does not specify who the kenâr müfîeri were, what their positions in the learned hierarchy were, why they were appointed, or in what manner. He merely explains that their rank is lower than the chief mufti's. Their lower rank is reflected in the require-

14 Mundy and Smith have noticed this treatise as well, see ibid, 22.

15 Mustafa Na'îmâ, Târih-i Na'îmâ: Ravzatü’l-Hüseyin fî Hulâsati Ahbâri’l-Hâfikayn (Ankara: Türk Tarih Kurumu, 2007), vol. 2, 424.

16 Colin Imber, Ebu's-Su'ud: The Islamic Legal Tradition (Stanford: Stanford University Press, 1997$), 7$. See also: Richard Repp, The Müfti of Istanbul.

17 Although written in the second half of the seventeenth century (completed in 1675-1676), Hezarfen relied on older documents, such as "kânûnnâmes, histories, old and new registers," as well as on other documents and registers from the court and the Imperial Divan. Hezârfen Hüseyin Efendî, Telhîṣü’l-Beyân fî Kavânîn-i Âl-i Osmân (Ankara: Türk Tarih Kurumu Basımevi, 1998), 38.

18 Hezârfen Hüuseyin Efendî, Telhîsü’l-Beyân, 197. 
ment to mention the authoritative text (nukûl) they used for their ruling, whereas the chief mufti was not supposed to do so. ${ }^{19}$

The anonymous author of Hirzü'l-Müluk, a treatise written several decades earlier and dedicated to the structure of the Ottoman state, provides additional details concerning the history of the office of the provincial mufti. According to this treatise, the main reason for the appointment of jurists as mufti in specific localities was to facilitate the access to a mufti without having to go to Istanbul. This may suggest that before this development took place, there had been only a single official mufti, who had resided in the Ottoman capital. Therefore, solicitors who wanted to obtain a jurisprudential ruling had had to travel to Istanbul for that purpose. The idea was to offer the provincial subjects authoritative rulings in the province. Later, in the author's time, the main purpose of the provincial mufti was to check oppressive officials and ignorant judges (zaleme-i vulât ve cehele-i kudât), who did not follow the rules of the şerîa. ${ }^{20}$

Whatever the original intention was, from the second half of the fifteenth century muftis were appointed to major urban centers across the central lands of the empire. Following the Ottoman conquest of the Arab lands and their subsequent incorporation into the empire, this practice was introduced to these parts of the empire as well. ${ }^{21}$ Although the information about lesser urban centers is partial, at least from the seventeenth century, it seems that the state-appointed muftis operated in these towns as well. ${ }^{22}$

The relationship between the chief imperial mufti, "the chief source of juristic authority," and his provincial counterparts merits a few words. For understanding the nature of this relationship it is necessary to examine the doctrinal definition of the office of the şeyhülislam within the Ottoman religious-judicial establishment. The legal rulings (fetâvâ) issued by the chief muftis over the course of the sixteenth and the seventeenth century serve as an important venue in which his authority was established. As time wore on, chief muftis increasingly underscored the binding nature of their legal opinions. Thus, all the members of the Ottoman religious-judicial establishment, muftis and judges alike, were to follow the chief mufti's rulings.

Consider, for instance, the following fetvâ. The seventeenth-century şeyhülislâm Yahyâ Efendî (d. 1643) was asked about a provincial mufti who permitted the remarriage of a couple after the wife had been triple-divorced but had not been married to another husband in between (hilla). This permission was against the ruling of the

19 Ibid., 200. See also: Uriel Heyd, "Some Aspects of the Ottoman Fetva”, Bulletin of the School of Oriental and African Studies, 32 (1, 1969): 45-46.

20 Anonymous, Hırzu'l-Mülûk in Yaşar Yücel, Osmanlı Devlet Teşkilâtına dair Kaynaklar (Ankara: Türk Tarih Kurumu, 1988), 192.

21 Repp, Müfti, 62-68.

22 Khayr al-Dīn al-Ramlī, for instance, obtained a state appointment for his nephew to serve as the state-appointed mufti of the Palestinian city of Ramla. al-Muhibbī, Khulāṣat al-athar, Vol. 3, 396-397. 
chief mufti. ${ }^{23}$ Accordingly, the chief mufti ruled that the provincial mufti should be punished (ta'zīr) and banned from issuing legal rulings (iftâ'dan men' lâzimdir). The same chief mufti also ordered the removal of a judge from office who ruled against the chief mufti's, perhaps his own, ruling. ${ }^{24}$

The removal of a mufti from office is of particular relevance to our discussion, for this is perhaps the most radical difference between the Ottoman perception of this institution and the understanding of the muftiship in other Islamic societies. More specifically, the Ottoman perception of the muftiship, as al-Murādī's introductory comment suggests, was substantially different from the perceptions of the office that prevailed in Mamluk sultanate prior to the Ottoman conquest. It is beyond the scope of this essay to explore the institution of the mufti under the Mamluks. Suffice is to say that at least in the fourteenth and the fifteenth century every scholar who was granted a permit to teach law and issue legal opinions (ijāzah fĩ al-tadrīs wa-l-iftā') by his teacher (or teachers) could have, at least theoretically, issued a legal ruling. ${ }^{25}$ At the same time, with the exception of the muftiship of the Hall of Justice ( $D \bar{a} r$ al- $A d l),{ }^{26}$ the mufti was not an office, as was the case under the Ottomans, but rather a status.

Moreover, despite the plurality of muftis, it should be emphasized that their rulings were not binding, as opposed to the judge's resolution in court. Nevertheless, Mamluk judges and rulers found at times the plurality of muftis disturbing and some of them even tried to limit it. ${ }^{27}$ But it is important to note that the argument

23 Yahyyâ Efendî, Fetâvâ, MS Ayasofya 1569, 88a.

24 Ibid., 84b. Similar ruling is recorded Abdü’r-Rahîm Efendî’s fetâvâ collection. Haim Gerber, State, society, and law in Islam: Ottoman law in comparative perspective (Albany: State University of New York Press, 1994), 81 (and 201, f.n. 3).

25 For an excellent discussion of this institution see: Devin Stewart, “The Doctorate of Islamic Law in Mamluk Egypt and Syria," in Law and Education in Medieval Islam: Studies in Memory of Proefessor George Makdisi, eds. Joseph E. Lowry, Devin J, Stewart and Shawkat M. Toorawa (Cambridge: The E J W Gibb Memorial Trust, 2004), 45-90.

26 On Dār al-'Adl and its muftiship see: Emile Tyan, Histoire de L'organisation Judiciaire en Pays D’Islam(Leiden: Brill, 1960), 433-525; Jørgen S. Nielsen, Secular Justice in an Islamic State: Mazālim under the Bahri Mamlūks 662/1264-789/1387 (Leiden: Nederlands Historisch-Archaeologisch Instituut te Istanbul, 1985), 49-173; Nasser O. Rabbat, “The Ideological Significance of the Dar al-'Adl in the Medieval Islamic Orient," IJMES, 27 (1), 3-28; Jon E. Mandaville, The Muslim Judiciary of Damascus in the late Mamluk Period(Princeton: Unpublished Ph.D. dissertation, 1969), 5-11, 69-73. In the fourteenth century there were official muftis affiliated with the four legal schools present in every session of the Hall in Cairo. In Damascus, on the other hand, in the late Mamluk period only the Hanafi and Shafi'I schools were represented. Jon Mandaville has suggested that in late fifteenth-century Damascus, only a Hanafi mufti attended the sessions of Dar al-'Adl in the city. Nevertheless, al-Ghazzì mentions a Shafi'i mufti as well. Najm al-Dīn al-Ghazzī, al-Kawākib al-sā’ira bi-a'yān al-mi'a al-'āshira (Beirut: al-Maṭba'ah al-Amrīkiyya, 1945), vol. 1, 40-45.

27 Lutz Wiederhold, "Legal-Religious Elite, Temporal Authority, and the Caliphate in Mamluk Society: Conclusions Drawn from the Examination of a "Zahiri Revolt” In Damascus in 1386," International Journal of Middle East Studies, 31 (2), 199: 320; Morimoto Kosei, "What Ibn Khaldūn Saw: The 
raised by al-Murādī concerning the constant strife and dispute between and amongst scholars and jurists was rarely raised in sources from the Mamluk period. It seems that al-Murādī's argument stems from a different set of concerns and from a different understanding of the muftiship.

The Egyptian jurist Zayn al-Dīn Ibn Nujaym's (d. 1562) opinion on this issue is particularly important. ${ }^{28}$ Writing in Egypt in the first decades following the Ottoman conquest, Ibn Nujaym has argued that the imām, in this case the sultan, should examine who is eligible to issue fatāwá from amongst the jurists and should prevent incompetent jurists from obtaining this position. Ibn Nujaym advocates an institutional solution to the plurality of muftis, but his solution is different from the Ottoman understanding of the office. As we shall shortly see, this statement stands at the center of the interpretative controversy between al-Ḥaṣkafī and al-Nābulusī.

\subsection{IV}

Late in the seventeenth century or early in the following century, ${ }^{29}$ 'Abd al-Ghani al-Nābulusī penned an epistle in which he responded to a treatise composed by al-Ḥaṣkafī, most likely 'Alā' al-Dīn al-Ḥaṣkafī. Although al-Ḥașkafī’s treatise is missing, it is clear that debate was centered on the nature of the muftiship in the seventeenth century. 'Alā' al-Dīn al-Ḥașkafī, as has already been mentioned, was a stateappointed mufti in Damascus. Despite the absence of al-Hașkafî’s own voice in this debate, ${ }^{30}$ it seems that al-Murādī's introduction echoes some issues that al-Ḥașkafī presumably touched upon in his absent treatise.

Al-Nābulusī opens the treatise with a discussion concerning who should be considered mufti. He explicitly states that "the muftiship is not like judgeship which is assigned by the sultan to a single person exclusively, as the people of this time do [i.e. as is the common practice in his own time]". ${ }^{31}$ Al-Nābulusī bases this statement on his understating of the state of the Hanafi school in his time. Following Ibn

Judiciary of Mamluk Egypt,” Mamluk Studies Review, 6, 2002: 109-131.

28 Cited in al-Nābulusī's treatise, see f.n. 37 below.

29 The epistle was copied by Muhammad b. Muṣtafā, most likely Muhammad al-Dakdakjī, a close disciple of al-Nābulusī, who was also acclaimed for his copyist skills. He is known to have written several works for al-Nābulusī. al-Dakdakjī died in 1718, so the treatise must have been completed earlier. On al-Dakdakjī, see: von Schlegell, Sufism in the Ottoman Arab World, 55-60.

30 al-Hașkafĩ discusses some of these issues in his commentary on Multaqā al-Abhur, entitled alDurr al-muntaqá fī sharh al-Multaqá, but he does not address the sultanic appointment of muftis. Muḥammad ibn 'Alī ibn Muhammadal-Ḥișnī l-ma'rūf bi-al-'Alā’ al-Ḥașkafī, al-Abhur, entitled al-Durr al-muntaqá fī sharh al-Multaqá (Beirut: Dār al-Kutub al-'Ilmiyya, 1998), vol. 3, 214-216.

31 'Abd al-Ghanī al-Nābulusī, al-Radd al-wafī 'alá jawāb al-Ḥaskafī 'alá mas'alat al-khiff al-Hanafī, MS Es’ad Efendî 1762, 153b. 
Nujaym's al-Baḥr al-rā'iq ${ }^{32}$ and Ibn al-Humām's Fatḥ al-qadīr, ${ }^{33}$ al-Nābulusī claims that a mufti should be a mujtahid, ${ }^{34}$ that is, a jurist who is allowed to exert his own juristic effort (ijtiha $\bar{d}$ ) for reaching a rule or an opinion. ${ }^{35}$ But the problem, according to al-Nābulusī, is that at his time there is not any jurist who may be considered mujtahid, as the eponymous founder of the Hanafī school Abū Hanīfa was. Instead, there are only jurists who preserve and transmit the opinions of previous mujtahids. Thus the muftis of his time, al-Nābulusī concludes, are not truly muftis but the transmitters of the sayings of the Mufti for the solicitor. The opinion can be transmitted either through a chain of transmission or through well-known and reliable texts, such as al-Marghīnānī’s al-Hidāyah or al-Sarkhasī's al-Mabsūṭ. If there are multiple opinions, issued by different mujtahids, the follower (muqallid) is free to choose any of these opinions. ${ }^{36}$

Returning to the sultan's appointment of muftis, al-Nābulusī admits that Ibn Nujaym states that the imām should examine who is eligible to issue legal rulings from amongst the jurists and should prevent incompetent jurists from obtaining this position. But, al-Nābulusī qualifies, Ibn Nujaym's statement should not be understood as a justification for appointing a single mufti whenever there are several eligible jurists. Therefore, al-Nābulusī concludes, every person who fulfils the requirements in terms of knowledge could issue legal rulings. ${ }^{37}$

As far as al-Nābulusī and his non-appointed colleagues were concerned, the plurality of muftis was crucial, as it legitimated their activity. Therefore, the argument al-Nābulusī advances is not simply a theoretical discussion, but a defense of a scholarly practice that permitted his own and others' activity as muftis. Read from this perspective, his treatise echoes the concerns of non-appointed jurists who were possibly threatened by the Ottoman appointment policy. More generally, al-Nābulusī's treatise brings to the surface a different understanding of jurisprudential authority and its transmission. By doing so, he poses a serious challenge to the institution of the state-appointed mufti in particular, and to the soundness of the Ottoman appointment policy of muftis in general.

Given al-Nābulusī’s immense popularity, al-Murādī must have been familiar with at least some of the arguments raised in al-Nābulusì's treatise, and perhaps even with the treatise itself. Specifically, he must have been aware of the tension

32 al-Nābulusī, al-Radd, 103b-104a. al-Ḥașkafī, in his commentary on Multaqá al-abḥur, shares this observation. al-Ḥașkafī, al-Durr al-muntaqá, vol. 3, 215.

33 al-Nābulusī, al-Radd, 154b.

34 Ibid.

35 On mujtahid and ijtihād: Wael B. Hallq, The Origin and Evolution of Islamic Law (Cambridge: Cambridge University Press, 2005), 128-132; Ibid., Authority, Continuity, and Change in Islamic Law (Cambridge: Cambridge University Press, 2004), 1-24.

36 al-Nābulusī, al-Radd, 154b.

37 Ibid., 154b-155a. 
between the concept of the muftiship as it appears in late Mamluk sources (as well as in later sources from the Arab lands) and the Ottoman practice of appointing muftis. al-Murādī's introduction, then, might be read as a response to these arguments. Thus, al-Murādī employs several arguments that are not the arguments made in the late Mamluk jurisprudential texts, such as the need to prevent disputes among the jurists. al-Murādī is also aware of the novelty in the Ottoman understanding of the muftiship. For these reasons, al-Murādi is compelled to admit that the practice of appointing muftis is rooted in the Ottoman kânûn which in turn is "compatible with the shari ah."

In this way, the imaginary dialogue between al-Nābulusī and al-Murādī is of relevance for understanding the relationship between "kânûn" and "shari'a". This is the main focus of the next and concluding section.

\section{$5.5 \mathrm{~V}$}

[...] when he entered Damascus, he renewed its affairs, implemented his edicts in it, and organized it according to his exalted qānūn which is in accordance to the honorable shar'. [He also] arranged its [the city's] offices of knowledge and siyāsah according to his ability and his noble opinion.

The definition of kânûn and shari’a (or şerîat) in the Ottoman context and the relationship between these concepts have drawn considerable scholarly attention over the past decades. ${ }^{38}$ One of the approaches to these questions perceives kânûn and şerî at first and foremost as two supplementary, often "kneaded together," components of the Ottoman legal discourse. Other scholars, however, have approached this question from a somewhat different angle. While not disregarding its discursive dimension, these scholars have pointed to the fact that kânûn also denotes various administrative and institutional practices prevalent across the empire. These practices, it should be stressed, were not necessarily codified, but were generally referred to as kânûn. Furthermore, although the institutional practices were not always codi-

38 Several studies have dealt with different aspect of these issues. Here are some relevant examples: Halil Inalcik, s.v. "Kânûn," EI²; Uriel Heyd, Studies in Old Ottoman Criminal Law(Oxford: Clarendon Press, 1973); Colin Imber, Ebu's-Su’ud; F. Babinger, s.v."Nishandji," EI²; Molly Greene, A Shared World: Christians and Muslims in the Early Modern Mediterranean (Princeton: Princeton University Press, 2000), 27-32; Timothy J. Fitzgerald, Ottoman Methods of Conquest: Legal Imperialism and the City of Aleppo, 1470-1570(Harvard University: Unpublished Ph.D. dissertation, 2009),188-195; Dror Ze'evi, Producing Desire: Changing Sexual Discourse in the Ottoman Middle East, 1500-1900 (Berkeley: University of California Press, 2006), 50. 
fied and were constantly negotiated and reconfigured, ${ }^{39}$ the kânûn as legal discourse served to legitimize these practices. The task, then, is to define what kânûn means in a specific historical context and the implication of this definition for understanding the relation between kânûn and şerîat.

The development of the Ottoman religious-judicial establishment is a good example of these dynamics. As Richard Repp has demonstrated, the consolidation of the Ottoman religious-judicial establishment was a direct outcome of a series of imperial edicts and legal codes (kânûnnâmes). ${ }^{40}$ The emergence of the şeyhülislam's office and those of his subordinates was also part of this process. To be sure, the fact that the hierarchy was established through these edicts does not necessarily preclude the participation of jurists in this process. Moreover, one should be careful not to assume that the jurists' involvement was instrumental. Instead, it is possible that the jurists in the core lands of the empire genuinely tried to articulate a religious-political vision that would be compatible with their understanding of the şerîat. Yet, this does not alter the fact, as al-Murādī observes in the introduction, that it was the imperial edicts that legitimized these institutional developments and specifically the emergence of a particular understanding of the muftiship (and especially of the chief muftiship) within the Ottoman establishment.

The latter point is of particular relevance to the aforementioned debate, since the Ottoman understanding of the muftiship assumed that the content of the şeri at was determined by the chief mufti. The latter, in turn, was a product of specific Ottoman administrative and institutional practices, the kânûn. From an institutional perspective, then, kânûn and şerî at were not exactly equal in the Ottoman context, for the content of şeríat, that is a particular version of the Hanafī school, was defined by an officeholder, the chief mufti, whose authority to endorse an opinion (and to exclude others) rested on the kânûn. As al-Murādī argues, however, many members of the Ottoman religious-judicial establishment claimed in what seems to be a cyclical argument that this practice was compatible with the şerî at.

To conclude, the encounter of two different perceptions of the muftiship in the Ottoman province of Damascus may serve as a laboratory to examine the relationship between different perceptions of şerî at (or shari’a). The debate outlined above makes clear that both parties understood what was at stake was not merely a procedural issue. Beyond the procedural or institutional aspects, the debate was about defining which Hanafi opinions should be applied as well as about the range of acceptable opinions within the Hanafī school. While the Ottoman religious establishment

39 Başak Tuğ, Politics of Honor: The Institutional and Social Frontiers of "Illicit" Sex in Mid-Eighteenth-Century Ottoman Anatolia(New York University: Unpublished Ph.d. Dissertation, 2009), 4096; Cornell H. Fleischer, Bureaucrat and Intellectual in the Ottoman Empire: The Historian Mustafa Âli (1541-1600)(Princeton: Princeton University Press, 1986), 191-200.

40 Repp, Müfti of Istanbul. 
sought to limit the range of applicable views within the schools, muftis who were not appointed by the state, such as al-Nābulusī, envisioned a wider range. From the latter's perspective, this was intended to defend the legitimacy of other Hanafī scholarly traditions, not necessarily those endorsed by the Ottoman religious-judicial establishment, within the Ottoman imperial framework. 